Original Research Paper

\title{
Pemulihan Wisata Pantai Telawas Era New Normal dengan Menerapkan Protokol Destinasi di Desa Mekar Sari Kecamatan Praya Barat
}

\author{
Lalu Iqra Hafiddin ${ }^{*}$, Lalu Rizki Rensa Kurniawan', Lalu Sofyan Assauri' ${ }^{1}$, Khaeril Ammar1, Irpan Manik \\ Pujiana $^{1}$, Nuriadi ${ }^{2}$ \\ ${ }^{1}$ Program Studi Ilmu Hukum, Fakultas Hukum, Universitas Mataram, Mataram, Indonesia \\ ${ }^{2}$ Program Studi Bahasa Inggris, Fakultas Keguruan Dan Ilmu Pendidikan, Universitas Mataram, Mataram, Indonesia
}

https://doi.org/10.29303/jpmpi.v3i2.616

Sitasi: Hafiddin, L. I., Kurniawan, L. R. R., Assauri, L. S., Ammar, K., Pujiana, I. M., \& Nuriadi. (2021). Pemulihan Wisata Pantai Telawas Era New Normal dengan Menerapkan Protokol Destinasi di Desa Mekar Sari Kecamatan Praya Barat. Jurnal Pengabdian Magister Pendidikan IPA, 4(1)

\section{Article history}

Received: 05 Desember 2020

Revised: 30 Desember 2020

Accepted: 04 Februari 2021

*Corresponding Author: Lalu Iqra Hafiddin, Program Studi Ilmu Hukum, Fakultas Hukum, Universitas Mataram, Mataram, Indonesia

Email:

iqrahafiddin6@gmail.com

\begin{abstract}
Pariwisata merupakan sektor industry yang penting untuk menigkatkan pendapatan masyarakat dan Negara. Kompleksitas dari Pandemi Covid - 19 telah merubah pola interaksi social tak terkecuali sektor pariwisata. Perencanaan dan pemulihan dalam sektor pariwisata melalui penerapan protocol kesehatan mulai dari edukasi, penggunaan masker, menyediakan hand sanitaizer di titik keramiaan destinasi, dan pemasangan pamphlet/baner untuk mematuhi protocol kesehatan. Tujuan dari program ini untuk memulihkan kembali destinasi wisata yang ada di Desa Mekar Sari Kecamatan Praya Barat, Kabupaten Lombok Tengah guna mengembalikan pendapatan masyarakat yang sempat turun drastis akibat pandemic Covid - 19 dengan bersandar pada protocol kesehatan. Program ini menggunakan penelitian kualitatif dengan pendekatan deskriptif. Kemudian pengolahan data di analisis yang disajikan dalam bentuk kesimpulan. Hasil dari program ini berupa panduan pemulihan pariwisata yang berbasis pada protocol kesehatan yang akan disebut sebagai protocol destinasi wisata.
\end{abstract}

Keywords: Protokol Destinasi; Destinasi Wisata Era New Normal.

\section{Pendahuluan}

Mekar Sari adalah salah satu desa yang terletak di Kecamatan Praya Barat, Kabupaten Lombok Tengah, Provinsi Nusa Tenggara Barat, Indonesia. Desa ini sebagian besar penduduknya bersuku Sasak. Secara geografis Desa Mekar Sari terletak diantara $0,34^{\circ}-1,23^{\circ}$ Lintang Selatan, Desa Mekar Sari memiliki Luas wilayah $3.761 \mathrm{~km}^{2}$, terbagi menjadi 9 dusun. Wilayahnya sendiri berbatasan dengan Kecamatan Pujut disisi Timur dan Praya barat Daya disisi barat, dengan apitan desa sebelah barat adalah desa Selong belanak dan apitan sebelah timur adalah desa prabu sementra posisi sebelah selatan desa mekar sari adalah lautan lepas dan sebelah utaranya adalah pegunungan.
Wilayah topografi dari Desa mekar sari ini, atas lembah dan daerah perbukitan yang potensial untuk pengembangan sektor pertanian, perkebunan, dan wisata wisata pantai dan perbukitan) dengan luas wilayah mencapai 3.761 Ha. Desa Mekar sari terdiri dari pemukiman, lahan pertanian, perkebunan, hutan, dan pantai. Sampai saat ini, desa mekar sari telah mampu menjadi produsen bagi beberapa hasil pertanian, peternakan, dan perkebunan, terkhusus menjadi salah satu icon pariwisata di wilayah Propinsi Nusa Tenggara Barat.

Desa mekar sari mempunyai potensi yang besar dalam hal wisata jika ditinjau dari kekayaan alam (tempat wisata, pantai yang indah) yang dimilki. Desa mekar sari mempunyai berbagai macam wisata diantaranya yaitu Desa Mekar Sari 
memiliki pemandangan alam yang sangat indah, asri, dan juga memiliki potensi alam yang dijadikan sebagai destinasi wisata andalan diantaranya yaitu Pantai Telawas, bukit perkemahan Telawas dan masih banyak pantai-pantai maupun bukit yang belum dibuka dan dijadikan icon destinasi pariwisata Desa. Sehingga pemanfaatan potensi desa terutama di bidang pariwisata ini akan maksimal. Hal ini tentu dikarenakan kurangnya kesadaran dan kurangnya koordinasi antar masyarakat dalam membangun dan memanfaatkan sumber daya alam (SDA) di Desa Mekar Sari dan juga kurangnya support pemerintah Daerah maupun Pemerintah Pusat dalam pengembangan pembukaan tempat wisata pantai-pantai baru yang sebenarnya sangat indah di desa mekar sari ini. Berbicara tentang salah satu tempat pariwisata yang banyak di kunjungi oleh wisatawan local maupun mancanegara yaitu pantai Telawas di dusun Gubk tengak. Pantai yang begitu sempurna untuk memanjankan mata serta potensi untuk menarik wisatawan untuk berkunjung ke Desa mekar sari untuk melihat keaslian dan keindahan pantai dengan pasir putih ditambah dengan panorama teluk pantai dengan bukti - bukit kecil yang mengelilinginya membuatnya menjadi destinasi wisata yang tak kalah sempurna untuk di kunjungi.

\section{Protocol Kesehatan di Tempat Pariwisata.}

\section{Sektor Kuliner}

Sektor kuliner sangat penting dalam marketing pariwisata. Di sisi lain, kuliner juga merupakan sektor yang mudah sekali menjadi agen penularan covid- 19. Untuk itu pelaku pariwisata yang bergerak dalam bidang kuliner, contohnya restoran, warung makan, toko oleh-oleh makanan dan sebagainya harus mematuhi berbagai protocol sebagai berikut:

- Fasilitas desinfektan tersedia di pintu masuk dalam bentuk hand sanitizer tangan berbasis alkohol yang sesuai atau fasilitas cuci tangan dengan sabun

- Staf restoran dilatih dan mematuhi pedoman kesehatan, kebersihan, dan kontak fisik yang serupa

- Hindari penanganan makanan oleh tamu sendiri di prasmanan, tawarkan kepada tamu untuk disajikan di meja secara a la carte atau bila memang menghendaki prasmanan, pastikan ada staf dengan APD standar (masker, face shield, sarung tangan food grade) yang bertugas membantu mengambilkan makanan.

- Pembersihan secara teratur mesin kopi / minuman dan sebisa mungkin dioperasikan oleh staf

- Pembersihan yang ditingkatkan, termasuk disinfektan meja dan kursi setelah tamu pergi dan sebaiknya menggunakan mesin pencuci piring (dish washer)bila tersedia

- Meminimalkan kontak fisik melalui jarak meja dan tempat duduk tamu, Pertimbangkan meminimalkan apa yang ditempatkan di meja tamu dan menyediakan barang yang dikemas secara tunggal

- Tinjau metode pembayaran, prioritaskan metode contactless dan pra-bayar (pembayaran menggunakan kartu dibanding tunai, uang elektronik (DANA, GOPAY, OVO dll) dibanding kartu)

- Pertimbangkan memiliki jam buka lebih lama untuk mengurangi jumlah tamu yang dilayani pada waktu tertentu dan fasilitasi penerapan aturan baru tersebut. Dianjurkan pembatasan tamu dan reservasi terlebih dahulu

\section{Operator Wisata}

Ketika operator wisata mulai beroperasi, mereka harus memastikan mereka dapat mengoptimalkan kualitas dan pengiriman operasional dan telah melatih staf untuk mempersiapkan dan melaksanakan rencana operasional:

- Pengelola wisata telah siap beroperasi kembali dengan memiliki: Memperoleh lisensi pembukaan kembali yang berlaku jika diminta oleh pemerintah daerah

- Mengembangkan rencana pencegahan COVID19 termasuk tindakan / checklist untuk pencegahan infeksi dan rencana pembersihan dan desinfeksi khusus

- Protokol dan pedoman yang diterapkan untuk kesehatan staf, termasuk pemeriksaan kesehatan untuk staf. Jika tidak diperlukan, operator tur mengeluarkan dan mengomunikasikan kebijakan stayhome untuk siapa saja yang menunjukkan gejala apa pun sesuai pedoman Organisasi Kesehatan Dunia (WHO)

- Menerapkan physical distancing dalam tata letak kantor dan membatasi jumlah staf di area umum di mana mungkin jika diperlukan oleh undangundang setempat 
- Protokol yang diterapkan untuk meminimalkan kontak fisik. Menerapkan protokol physical distancing Alat perlindungan diri (APD) yang tersedia untuk staf, seperti masker, google/face shield, selama diperlukan sesuai pendekatan berbasis risiko

- Teknologi terintegrasi untuk memungkinkan otomatisasi seperti pembayaran tanpa kontak jika memungkinkan. Jika pembayaran tanpa kontak tidak memungkinkan, pertimbangkan untuk menggunakan sarung tangan dan sanitasi tangan

- Meminta kepada pemasok dan mitra termasuk restoran, hotel, taman, mitra transportasi dan tempat wisata lain agar mereka mengikuti protokol kesehatan dan kebersihan yang serupa dan pedoman untuk melindungi para tamu seperti yang dipersyaratkan oleh undang undang

- Membuat rencana kontingensi COVID-19 jika kasus baru muncul bekerja sama dengan pihak terkait (Dinas Kesehatan/ Puskesmas/ Klinik/ RS)

- Mengidentifikasi dan mengadopsi praktik terbaik kebersihan dan desinfeksi yang divalidasi oleh badan pakar, otoritas kesehatan dan lembaga pemerintah

- Mengembangkan berbagai opsi untuk operasional, jika memungkinkan, seperti tiket lanjutan, pengaturan waktu masuk, grup yang lebih kecil, dan sistem reservasi

- Untuk tahap awal sebaiknya tidak semua wahana/destinasi wisata dibuka Operator wisata harus melatih semua staf mereka untuk mempersiapkan dan melaksanakan rencana operasional dengan:

- Membuat dan menerapkan protokol dan pedoman staf, termasuk pemandu wisata, coach/ pengemudi dan spesialis lokal

- Membekali staf dengan alat dan informasi yang diperlukan mengenai pengendalian infeksi, kontak fisik, berbagi makanan dan peralatan, pakaian yang sesuai, dan tindakan kebersihan yang ditingkatkan, penggunaan masker dan sarung tangan seperti yang direkomendasikan atau seperti yang disyaratkan oleh prosedur dari operator wisata

- Meminta pemangku kepentingan utama seperti mitra venue, hotel dan mitra transportasi untuk melatih staf mereka berdasarkan protokol yang serupa untuk memungkinkan pendekatan yang konsisten di seluruh sektor
- Semua pelatihan harus diinformasikan oleh saran terbaru dari otoritas kesehatan masyarakat dan atau WHO

- Pemantauan staf secara teratur oleh pemimpin, mendorong mereka untuk mengikuti pedoman pemerintah dan WHO

- Konfirmasi dengan pemasok proses-proses yang berfokus pada peningkatan sanitasi, desinfeksi, dan praktik pembersihan mendalam untuk coach/ pelatih dan kendaraan lain yang digunakan serta meningkatkan frekuensi pembersihan / desinfeksi:

- Produk desinfektan terpilih yang disetujui oleh otoritas kesehatan

- Pedoman yang telah direvisi untuk tim pembersih dengan fokus khusus pada titik sentuh frekuensi tinggi, termasuk pegangan tangan, pegangan pintu, meja, penutup toilet, filter pendingin udara, loker overhead dan headset jika berlaku. Tingkatkan frekuensi pembersihan seperlunya

- Produk desinfektan yang disetujui tersedia di stasiun sanitasi untuk para tamu dalam bentuk pembersih tangan berbasis alkohol yang sesuai. Berikan atau sediakan untuk tamu bila ingin membeli produk disinfektan individu tambahan

- Alokasikan tamu sesuai tempat duduknya, tidak boleh berpindah/ bertukar tempat. Terapkan jarak sesuai peraturan.

- Sediakan tempat sampah dengan kantong plastik di dalam dan pembuangan reguler o Biasakan bekerja dengan mitra transportasi yang telah memiliki proses yang standar untuk sanitasi, desinfeksi dan praktik pembersihan mendalam Pelayanan tamu dan meminimalkan kontak fisik:

- Melaksanakan pemeriksaan dan pengujian kesehatan tamu jika perlu

- Kontak fisik yang terbatas dan menjaga jarak dalam antrian jika memungkinkan

- Menyediakan masker untuk tamu

- Kembangkan online check-in dan check-out tanpa kontak

- Kembangkan hubungan dengan mitra dan pemasok, termasuk toko, ruang pamer, tempat mencicipi / toko, museum, pertunjukan, teater, ruang konser, pabrik \& pertanian, dimana mereka mengikuti protokol kesehatan, sanitasi, desinfeksi dan kebersihan yang serupa dengan peraturan lokal 
- Bekerja samadengan restoran mitra yang mengikuti protokol kesehatan, sanitasi, desinfeksi, dan kebersihan yang serupa untuk melindungi para tamu.

\section{Destinasi Wisata}

Destinasi wisata sebagai ikon pariwisata suatu daerah, sangat memegang peranan penting dalam kemajuan pariwisata suatu daerah. Destinasi Pariwisata, menurut UU no 10 tahun 2009 adalah kawasan geografis yang berada dalam satu atau lebih wilayah administratif yang di dalamnya terdapat daya tarik wisata, fasilitas umum, fasilitas pariwisata, aksesibilitas, serta masyarakat yang saling terkait dan melengkapi terwujudnya kepariwisataan yang termasuk dalam destinasi wisata antara lain desa wisata, objek wisata alam maupun buatan. Selama masa vakum kemarin, diharapkan pengelola destinasi wisata telah mempersiapkan diri menghadapi pembukaan destinasi wisata ini. Protokol standar yang wajib diperhatikan adalah sebagai berikut:

- Pastikan seluruh area umum bersih Melakukan pembersihan menggunakan desinfektan minimal 3 kali sehari terutama pada waktu aktivitas padat (pagi, siang dan sore hari) di setiap lokasi representatif (pegangan pintu, tombol lift, pegangan eskalator, dll.)

- Deteksi suhu tubuh di setiap titik pintu masuk tempat wisata Jika suhu tubuh masyarakat terdeteksi $\geq 38 \mathrm{oC}$, dianjurkan untuk segera memeriksakan kondisi tubuh ke fasilitas pelayanan kesehatan dan tidak diperkenankan untuk memasuki tempat wisata.

- Sementara menunda perhelatan besar yang mendatangkan masyarakat dalam jumlah banyak (contoh konser, seminar, dll). Bila ada pertemuan dibatasi max 20 peserta.

- Sementara membatasi pengunjung hanya dari wilayah DIY sampai ditentukan lain oleh Dinas setelah berkoordinasi dengan Gugus Tugas Penanggulangan Covid-19 Kabupaten Bantul

- Promosikan cuci tangan secara teratur dan menyeluruh.

- Pajang poster mengenai pentingnya cuci tangan dan tata cara cuci tangan yang benar.

- Pastikan tempat wisata memiliki akses untuk cuci tangan dengan sabun dan air atau pencuci tangan berbasis alcohol.

- Tempatkan dispenser pembersih tangan di tempat-tempat strategis dan mudah dijangkau masyarakat di tempat wisata dan pastikan dispenser ini diisi ulang secara teratur.

- Mensosialisasikan etika batuk/ bersin di tempat wisata.

- Pajang poster tentang mengenai pentingnya menerapkan etika batuk/ bersin serta tata cara bersin/ batuk di tempat wisata.

- Pengelola tempat wisata harus menyediakan masker wajah dan atau tisu yang diberikan untuk seluruh pengunjung dan penumpang yang mempunyai gejala flu atau batuk.

- Memperbaharui informasi tentang Covid-19 secara reguler dan menempatkan di area yang mudah dilihat oleh pengunjung.

- Menyediakan media komunikasi, informasi dan edukasi (KIE) mengenai pencegahan dan pengendalian Covid-19 di lokasi strategis di setiap tempat wisata.

- Bekerja sama dengan fasilitas kesehatan terdekat untuk prosedur perujukan wisatawan yang sakit dan peningkatan pengetahuan staf tentang alat perlindungan diri dan pencegahan infeksi.

Pengaturan ulang system ticketing, system pembayaran cashless, system reservasi di destinasi wisata. Khusus untuk desa wisata antrian reservasi ini sekaligus untuk mempersiapkan paket edukasi yang dipilih oleh wisatawan. 11 Pembatasan pengunjung sesuai dengan kapasitas petugas dan ratio wisatawan dibandingkan luas area lahan (sistem buka tutup).

\section{Metode}

Artikel ini menggunakan metode kualitatif deskriptif. Menurut Denzim dan Lincoln (dalam Setiawan, 2018) penelitian kualitatif adalah penelitian yang menggunakan latar alamiah dengan maksud menafsirkan fenomena yang terjadi dan dilakukan dengan jalan melibatkan berbagai metode yang ada. Sedangkan Erickson (dalam Setiawan, 2018) menyatakan bahwa penelitian kualitatif berusaha untuk menemukan dan menggambarkan secara naratif kegiatan yang dilakukan dan dampak dari tindakan yang dilakukan terhadap kehidupan mereka. Penelitian kualitatif bersifat deskriptif. Deskripsi dilakukan pada penggambaran apa adanya factor faktor yang terlibat dalam permasalahan tersebut. Pengambilan data pada program ini dilakukan dengan observasi lapangan, wawancara, dan studi pustaka yang selanjutnya 
dianalisis dengan melakukan penarikan kesimpulan. Hal ini didasarakan pada tujuan penelitian untuk menghasilakan panduan protocol destinasi wisata dalam krangka pemulihan parwisata di pantai Teluk Lawas yang terdampak oleh Covid - 19 .

\section{Hasil dan Pembahasan}

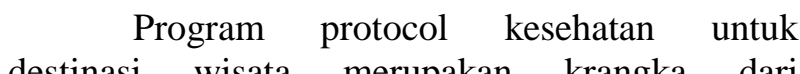
pemulihan pariwisata yang ada di Desa Mekar Sari Kecamatan Praya Barat, Kabupaten Lombok Tengah yang tepatnya adalah di Pantai Telawas. Untuk penyusunan protocol destinasi dilakukan survey dan observasi terhadap spot - spot yang ada di Pantai Telawas, adapun hasil dari survey dan obeservasi adalah sebagai berikut:

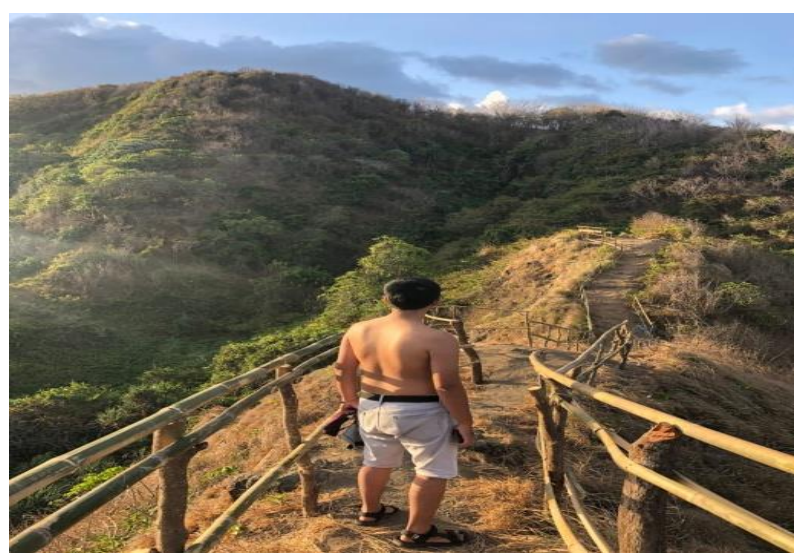

Gambar 1. Spot Foto (Area Bukit)

Spot foto yang ada di pantai telawas memiliki 2 bagian yakni dari bukit dan pantai. Bukit yang mengorbit pada Pantai Telawas membuat pemandangan sekelilignya menjadi ekosotik karena langsung dapat menikmati pantai secara langsung.

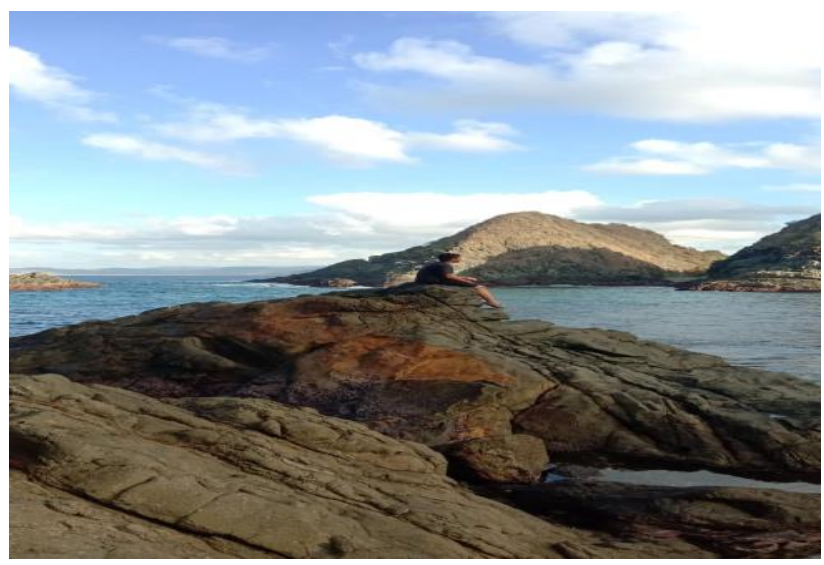

Gambar 2. Spot Foto (Area Pantai)
Bagian pada foto ini menampilkan icon utama dari Pantai Telawas.

Tidak hanya pemandangan pantai dan bukit, namun dalam area Pantai Telawas juga menyedikan lahan untuk Camping Ground lengkap dengan persipan api unggunnya.

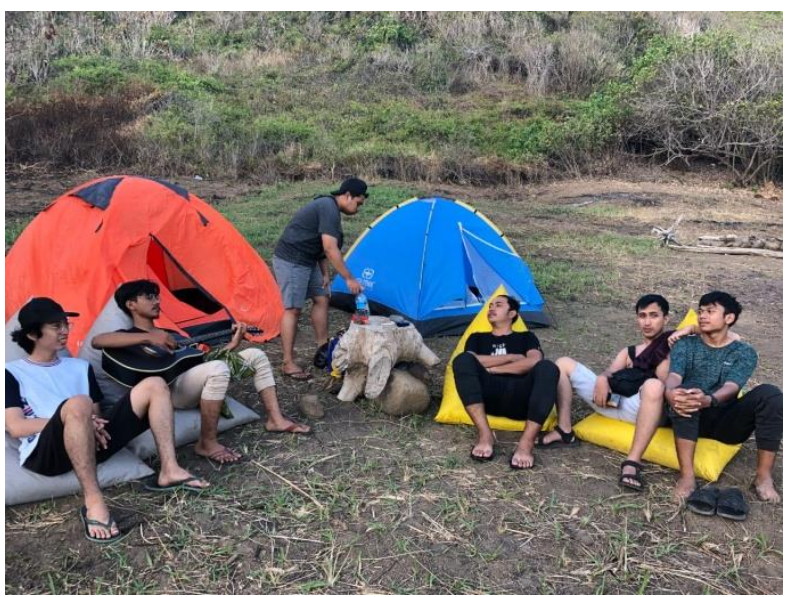

Gambar 3. Camping Ground

Area memanah adalah salah satu area yang menjadi daya tarik, karena tidak semua destinasi pariwista menawarkan area memanah.

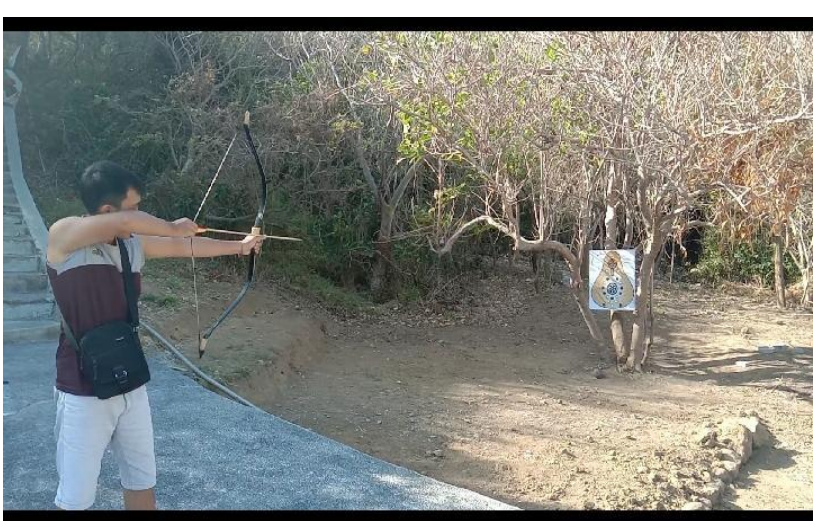

Gambar 4. Area Memanah

\section{Fasilitas Pendukung}

Di Pantai Telawas juga memiliki sarana dan prasarana yang mendukung untuk memberikan kenyamanan bagi para wisatawan adapaun saran dan prasarannya sebagai berikut:

1. Tempat parkir yang aman merupakan kenyamanan yang utama bagi para wisatawan. Rasa aman untuk berwisata dimulai dari tempat parkir, karena rasa nyaman menjadi bagaian yang penting dalam berwisata. 


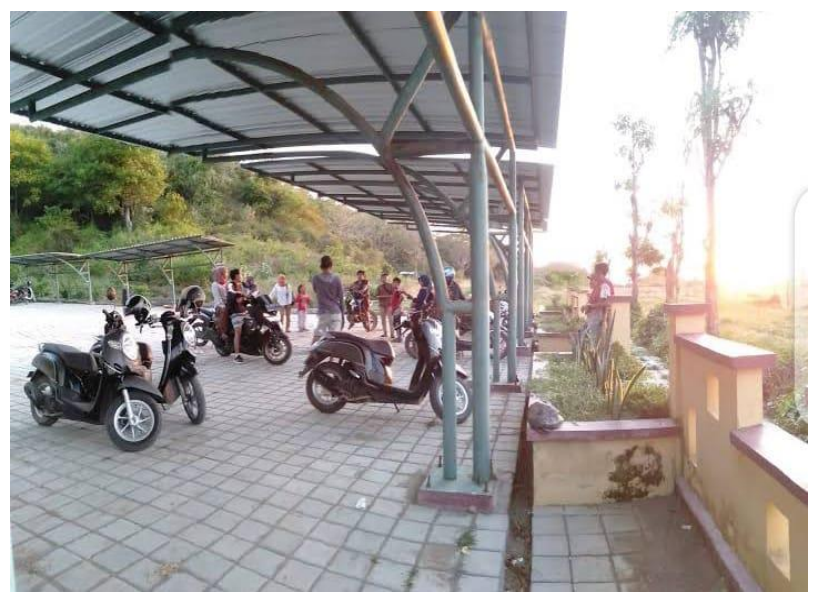

Gambar 5. Tempat Parkir

2. Fasilitas berugak yang berjejer ditepi pantai dapat digunakan untuk berteduh baik dari panas maupun hujan, sehingga para wisatawan tidak perlu cemas untuk selalu membawa tas atau barang - barang mereka.

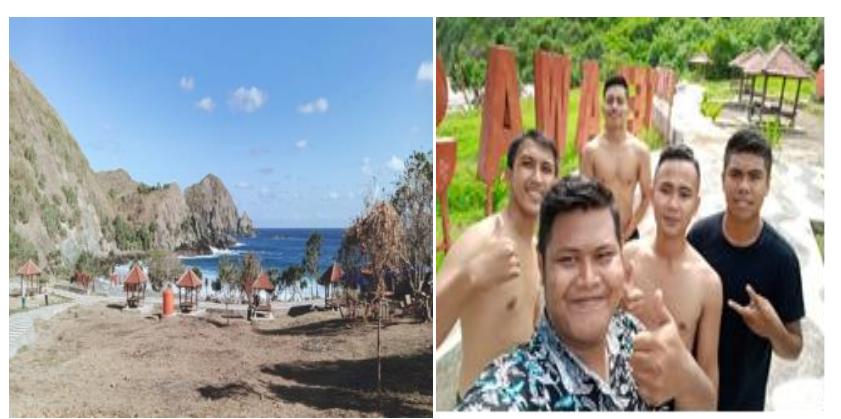

Gambar 6. Berugak

3. Bagi para wisatawan yang ingin berwisata sembari berolahraga, pantai Telawas menawarkan jalan setapak yang dapat dipakai untuk jalan - jalan menggunakan kaki maupun sepeda.

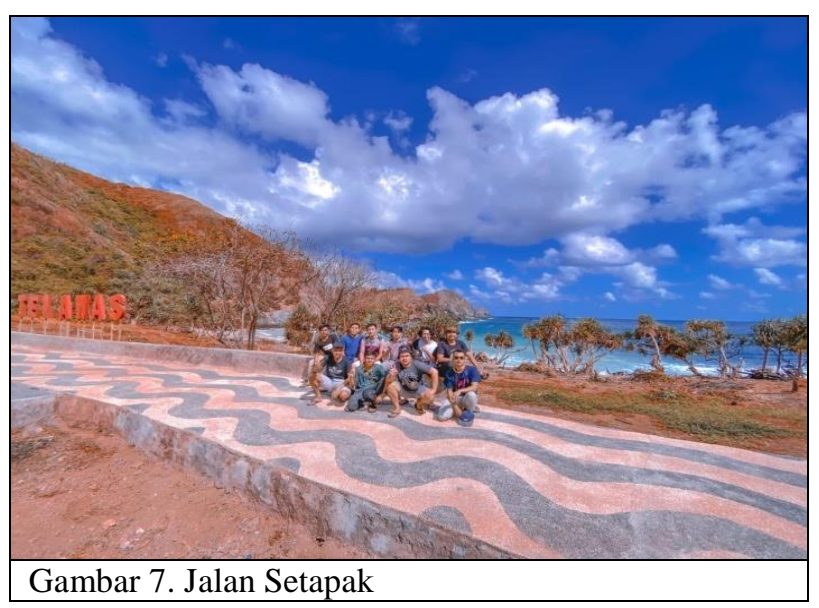

Pada bagian awal sudah dijelaskan secara umum bagaimana standar protocol kesehatan di tempat pariwisata, namun karena Pantai Telawas memiliki spot - spot yang berbeda maka terdapat perbedaan penerapan protkol keshatan yang ada di area Pantai Telawas. Berikut panduan protocol kesehatan untuk spot Pantai Telawas;

\section{Operator Wisata}

Informasi dan transformasi informasi kepada wisatawan dan masyarakat menjadi salah satu hal penting untuk diketahui mengenai perkembangan Covid - 19. Sehinga dalam hal ini diperlukan operator wisata yang bertugas mempublikasikan informasi terbaru mengenai Covid - 19 kepada masyarakat setempat dan pengunjung, gugus tugas khusus untuk memantau para pengunjung yang datang, serta menjadi tim yang siap siaga untuk antisipasi penyebaran Covid -19 .

Publikasi informasi dapat berupa papan informasi yang disedikan ditempat awal sebelum memasuki area Pantai Telawas yang memuat poin tentang protocol kesehatan, kemudian gugus tugas khusus adalah tim yang melakukan pegecekan terhadap pengunjung, dapat berupa pengecekan suhu sekaligus menjadejali garis koordinasi jika sewaktu - waktu dibutuhkan penaganan secara cepat terhadap gejala Covid -19 .

\section{Protokol destinasi}

1. Pastikan seluruh area umum bersih Melakukan pembersihan menggunakan desinfektan minimal 3 kali sehari terutama pada waktu aktivitas padat (pagi, siang dan sore hari) di setiap lokasi yang ada di Pantai Telawas;

2. Deteksi suhu tubuh di setiap titik pintu masuk tempat wisata Jika suhu tubuh masyarakat terdeteksi $\geq 38 \mathrm{oC}$, untuk pengecekan suhu dapat dilakukan sebelum memasuki area Pantai Telawas maupun ditempat parkir;

3. Promosikan cuci tangan secara teratur dan menyeluruh seperti pajang poster mengenai pentingnya cuci tangan dan tata cara cuci tangan yang benar, pastikan tempat wisata memiliki akses untuk cuci tangan dengan sabun dan air atau pencuci tangan berbasis alcohol, tempatkan dispenser pembersih tangan di tempat-tempat strategis dan mudah dijangkau masyarakat di tempat wisata dan pastikan dispenser ini diisi ulang secara teratur; 
4. Mensosialisasikan etika batuk/ bersin di tempat wisata Pajang poster tentang mengenai pentingnya menerapkan etika batuk/ bersin serta tata cara bersin/ batuk di tempat wisata, Pengelola tempat wisata harus menyediakan masker wajah dan atau tisu yang diberikan untuk seluruh pengunjung dan penumpang yang mempunyai gejala flu atau batuk;

5. Memperbaharui informasi tentang Covid-19 secara reguler dan menempatkan di area yang mudah dilihat oleh pengunjung;

6. Menyediakan media komunikasi, informasi dan edukasi (KIE) mengenai pencegahan dan pengendalian Covid-19 di lokasi strategis di setiap tempat wisata;

7. Bekerja sama dengan fasilitas kesehatan terdekat untuk prosedur perujukan wisatawan yang sakit dan peningkatan pengetahuan staf tentang alat perlindungan diri dan pencegahan infeksi;

8. Pengaturan ulang system ticketing, system pembayaran cashless, system reservasi di destinasi wisata. Khusus untuk desa wisata antrian reservasi ini sekaligus untuk mempersiapkan paket edukasi yang dipilih oleh wisatawan;

9. Pembatasan pengunjung sesuai dengan kapasitas petugas dan ratio wisatawan dibandingkan luas area lahan (sistem buka tutup).

\section{Kesimpulan}

Pantai telawas merupakan salah satu destinasi pariwisata unggulan dan prioritas di Desa Mekar Sari Kecamatan Praya Barat, Kabupaten Lombok Tengah. Sehingga pemulihan pariwisata di Pantai Telawas akibat dari Covid - 19 menjadi agenda yang penting guna mengembalikan pendapatan masyarakat. Pemulihan pariwisata di Pantai Telawas bersandar pada prtokol kesehatan sebagai kerangka awal untuk pemulihan. Protocol kesehatan yang dimkasud adalah adanya operator wisata yang menjadi garis koordinasi informasi Covid - 19 dan protocol destinasi yang berupa praktik secara langsung dalam pencegahaan yang dapat berupa; pembersihan area menggunkan desinfektan, deteksi suhu, promosi cuci tangan, sosialisasi etika batuk, update informasi Covid 19, penyediaan alat komunkasi pencegahan Covid 19, kerja sama dengan fasilitas kesehatan terdekat, pengaturan ulang system ticketing, dan pembatasan pengunjung dengan system buka tutup.

\section{Ucapan Terima Kasih}

Izinkan kami mengantarkan dari lisan yang penuh kekurangan ini ucapan terimakasih, teruntuk dosen pembimbing KKN Era New Normal 2021, Dosen Pembimbing Lapangan (DPL) kami Bapak Dr. Nuriadi, S.S., M. Hum. Yang telah bersedia membimbing dan mengantarkan kami menyelesaikan naskah ilmiah ini. Bingung, mungkin itu perasaan pertama yang menyelinap di hati beliau ketika pertamakali menghubungi dan menemui beliau tanpa surat tugas dari LPPM Universitas Mataram yang kami bawa, tapi dengan ramah beliau membukakan pintu rumah, dengan ikhlas membimbing kami.atas semua hal itu hanya ucapan terimakasihnyang tak terhingga yang bisa kami sampaikan.

\section{Daftar Pustaka}

Dinas Perhubungan, Pariwisata, Komunikasi dan Informatika Kabupaten Lombok Tengah Nusa Tenggara Barat.

Gugus tugas percepatan penanggulangan covid-19, 2020. Paket Panduan Lintas Sektor Tanggap COVID-19 - menuju situasi 'normal yang baru'.

Kemenkes RI, 2020. Surat Edaran Protokol Pencegahan Penularan Corona Virus Disease (Covid-19) di Tempat Kerja Sektor Jasa dan Perdagangan (area publik).

Kemenpar RI, 2018. SOP Pengelolaan Krisis Kepariwisataan.

Permana, Adi. 2020. "Dr. Nuning Nuraini bersama Tim SimcovID Sampaikan Kajian Ilmiah Terbaru Pandemi COVID-19 di Indonesia." Retrieved April 14, 2020, from https://www.itb.ac.id/news/read/57461/ home/dr-nuning-nuraini-bersama-timsimcovid-sampaikan-kajian-ilmiahterbaru-pandemi-covid-19-di-indonesia.

Setiawan, Johan dan Anggito, Albi. 2018. Metodologi Penelitian Kualitatif. Sukabumi: CV Jejak. 
Soekadijo, R. G. 2000. Anatomi Pariwisata Memahami Pariwisata Sebagai Systemic Linkage. Jakarta: Gramedia Pustaka Utama.

Spillane, James J. 1987. Pariwisata di Indonesia Sejarah dan Prospeknya. Yogyakarta: Kanisius.

Suwantoro, Gamal. 2001. Dasar-Dasar Pariwisata. Yogyakarta: Andi.

Taufan Rahmadi dan Liliek Setiawan. Buku Panduan Destinasi Pemulihan Wisata Era New Normal 2020.

Wahab, Salah. 2003. Manajemen Kepariwisataan. Jakarta: Pradnya Paranita.

World Travel \& Tourism Council, 2020. Leading Global Protocols for the New Normal.

Yurianto, Kirana Pritasari, Bambang Wibowo, And Siswanto. 2020. Pedoman Penanganan Cepat Medis dan Kesehatan Masyarakat Covid-19 di Indonesia. 